\title{
Influence of Activity Ratio to The Performance of Financial Statement of Badan BPJS Ketenagakerjaan Indonesia
}

\author{
Sultan, Dr Teddy Oswari²
}

1,2Faculty of Economics, Universitas Gunadarma, Jakarta, Indonesia

\begin{abstract}
In this study, the writer will analyze the influence of activity ratios on the performance of BPJS Ketenagakerjaan Agency's financial statements with the linear regression model approach. In this research, the author uses the measurement method of Standard Deviation, Historical Simulation and Variance Covariance approaches. The time span used in this research is from 2014 to 2018. This study is to find out how much influence the ratio of activity to return on assets on the BPJS ketenagakerjaan.
\end{abstract}

Keywords : BPJS Ketenagakerjaan, Liquidity Ratio, Leverage Ratio, Activity Ratio, Return on Assets

\section{INTRODUCTION}

Previously Badan Penyelenggara Jaminan Sosial (BPJS) Ketenagakerjaan was named Jamsostek (labor social security), which was managed by PT. Jamsostek (Persero), but according to UndangUndang (UU) No. 24 of 2011 about BPJS, PT. Jamsostek changed into BPJS Ketenagakerjaan since January 1, 2014. BPJS Kesehatan was formerly named Askes and BPJS Ketenagakerjaan are government programs in the Jaminan Kesehatan Nasional (JKN) which was official on December 31st, 2013. BPJS Kesehatan officially operate on January 1st, 2014, whereas BPJS Ketenagakerjaan began full operation since July 1st, 2015. In accordance with UU no.24 of 2011 about the Badan Penyelenggara (BPJS), clause 37 paragraph (1), BPJS Ketenagakerjaan has the duty of submitting responsibility for carrying out its duties in the form of program implementation reports and annual financial reports audited by public accountants to the President of the Republic of Indonesia with a copy to DJSN.
The provisions regarding the form and content of program management reports are regulated by Peraturan Presiden (Perpres). Based on Peraturan No. $108^{\text {th }}$, 2013, BPJS ketenagakerjaan has submitted a report on the management of social security programs which include:

1. Financial reports: Jaminan Kecelakaan Kerja Program (JKK)

2. Financial reports: Jaminan Kematian Program (JKM)

3. Financial reports: Jaminan Hari Tua Program (JHT)

4. Consolidated financial statements: BPJS, Subsidiaries and Special Purpose entities

5. Program Management Report.

This research will measure how many influence of the level of financial health on the financial performance of BPJS Ketenagakerjaan. To achieve this goal, the BPJS Ketenagakerjaan must submit the report accurately and completely within the settled time. To find out the level of health of BPJS 
Ketenagakerjaan's financial statement, it is necessary to analyze that report.

\subsection{Research purposes}

The purposes of this study are:

1. Knowing the influence of the Activity ratio represented by the $\mathrm{BOPO}$ ratio and the expense ratio divided by investment income $\&$ income to the financial statement performance represented by partial return on assets at the BPJS Indonesian BPJS ketenagakerjaan.

2. Knowing the effect of the Activity ratio represented by the $\mathrm{BOPO}$ ratio and the expense ratio divided by investment income \& income to the performance of the financial statements represented by return on assets simultaneously at the Indonesian BPJS Ketenagakerjaan.

\section{THEORY BASIS}

\subsection{Definition of Financial Statements}

\subsubsection{Financial Management}

The definition of financial management according to to Keown, Martin, Petty, and Scott (2005: 4) is Financial management is corcerned with maintenance and creation of economic value or wealth, which means that financial management is about maintaining and creating economic value or wealth. According to Sutrisno (2003; 3) Financial management is all company activities related to efforts to obtain company funds at a low cost and efforts to use and allocate that funds efficiently.

\subsubsection{Financial Statements}

The Indonesian Institute of Accountants (2012: 5) suggests the meaning of financial statements, namely: Financial statements are the structures that present the financial position and financial performance in an entity. The general purpose of these financial statements for the public interest is the presentation of information about the financial position, finance ( financial performance), and cash flow of the entity that is very useful for making economic decisions for its users. To achieve this goal, the financial statements provide information about the elements of the entity consisting of assets, liabilities, networth , expenses, and income (including gains and losses), changes in equity and cash flow. This information, followed by notes, will help users predict future cash flows. According to Munawir (2010: 5), financial statements generally consist of balance sheets and profit and loss statements and statements of changes in equity.

\subsubsection{Types of Financial Statements}

According to the Indonesian Institute of Accountants (2009: 2), a complete financial statement usually includes a balance sheet, income statement, statement of changes in equity, cash flow statement, and notes to the financial statements. In this research, the author uses a balance sheet and income statement.

\subsection{Income Statement}

\subsubsection{Revenue (results)}

Committe off terminology defines revenue as a result of selling goods or providing services that are charged to customers, or those who receive services. This definition uses the revenue expense approach. APB defines gross increase in assets and a decrease in gross liabilities assessed based on accounting principles derived from profit-making activities.

\subsubsection{Recognition of income}

Theoretically, revenue recognition is an income that will be recognized as income in the period when the main activities necessary to create and sell the goods and services have been completed. In this case there are four alternatives, namely during production, 
when the production process is complete, at the time of sale and at the time of cash collection.

\subsubsection{Fees}

APB defines as a decrease in gross assets or an increase in gross in liabilities that are recognized and valued according to the accounting principles received from profit seeking activities of the company.

\subsubsection{Gain}

Beyond the profits above there is another classification of profits outside the profit which is known as gain. According to the FASB Gains definition is an increase in the value of equity from transactions that are incidental and not the main activity of the entity and from transactions / other events that affect the entity for a certain period except those originating from the results or investments of the owner.

\subsubsection{Loses}

Loses are decreases in the value of equity from transactions which are nature and not the main activity of the entity and from all other transactions that affect the entity during a certain period except those that come from costs or giving to the owner ( prive).

\subsubsection{Ratio of financial health and financial performance}

According to wild, Subramanyam, and Hasley (2005), Ratio is a tool to provide a view of the underlying conditions. The ratio is one starting point, not an end point. Properly interpreted ratios indicate areas that require further investigation.

According to Kasmir (2012: 104), financial ratios are activities that compare the numbers in a financial statement by dividing one number with another number. Comparisons can be made between one component with the components in one financial statement or between components that exist between financial statements .

\section{RESEARCH METHOD}

\subsection{Research Object}

The object of this research is the agency engaged in the field of national guarantees namely the labor BPJS which has a public legal entity.

\subsection{Population}

Bpjs Ketenagakerjaan has branch offices spread throughout Indonesia, starting from the head office, regional offices, branch offices and pioneer branches. For branch offices there are 120 offices spread throughout Indonesia and there are 203 pioneer branch offices with 5957 active employees throughout Indonesia.

\subsection{Discussion of Research Results Data and Data Collection Techniques}

The data used by the author in this thesis requires adequate and accurate data as a basis for research. The type of data used in this study is secondary data, namely data obtained through sources in the form of Audited Financial Statements for 5 years starting from the 2014, 2015, 2016, 2017 and 2018 Financial Statements which have been published in several national media.

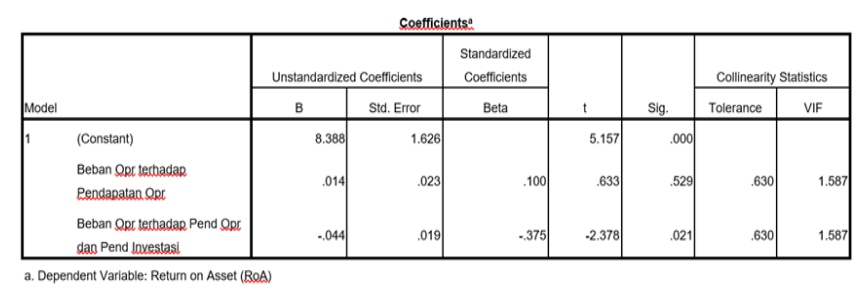

Figure 1. Collinearity Statistic 


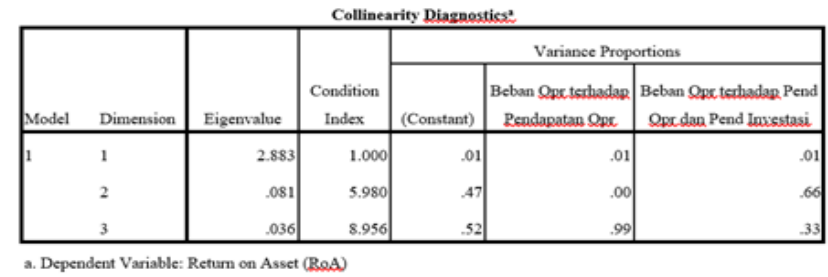

Figure 2. Collinearity Diagnostic

After analyzing the influence of the soundness of the performance of the financial statements BPJS Agency for employment, it can be concluded that the results of the analysis 's show that the ratio of activity has the Sig. $<0.05$, it can be said that there is a significant influence between the ratio of activities to the financial performance of the BPJS ketenagakerjaan Agency report.

\begin{tabular}{|c|c|c|c|c|c|c|}
\hline \multicolumn{7}{|c|}{ Adovab } \\
\hline Mo & & Sun of Squares & $\mathrm{DF}$ & Mean Square & $\mathrm{F}$ & Sig.. \\
\hline 1 & Regression & 89.906 & 2 & 44.953 & 3.351 & .042 \\
\hline & Residual & 764.694 & 57 & 13.416 & & \\
\hline & Total & 854,600 & 59 & & & \\
\hline
\end{tabular}

a. Predietors: (Constant), Beban Qprc terbadap Pend Qprdan Pend Inxestasi Beban Qpc terhadap Rendapatan Qpd b. Dependent Variable: Return on Asset (ReA)

Figure 3. Anova

\section{CONCLUSION}

Soundness (liquidity ratios, leverage ratios and activity ratios together have a significant effect on financial performance (return on assets) of the financial statements of the BPJS Ketenagakerjaan.

\section{REFERENCES}

[1]. Keown, Martin, Petty, and Scott (2005).': John Wiley \& Sons, Inc

[2]. Sutrisno (2003),' Financial Management Theories, Concepts and Applications' , First Edition, Second Printing, Ekonosia, Yogyakarta.

[3]. Indonesian Institute of Accountants, 2012,' Financial Accounting Standards', Jakarta: IAI.

[4]. Munawir S., 2010,' Analysis of Financial Statements, Fourth Edition, Thirteenth Printing', Liberty, Yogyakarta.

[5]. Harahap, Sofyan Syafri. 2010.' Financial Accounting Theory, First Edition' . Third edition, PT Bumi Aksara, Jakarta.
[6]. Gitman Marbun, Rocky et al (2012).' Complete Law Dictionary' . Jakarta: transmedia library

[7]. APB, Statement No.4 (1970).' Basics Concepts and accounting principles underlying financial Statements of Business Enterprice' .

[8]. FASB Original (1990 ).' Accounting Standards' Standards . Volume I, Irwin, Homewood, Illinois .

[9]. Riyanto, Bambang, ( 2010 ) ,' Fundamentals of Corporate Expenditures' , Fourth Edition, Seventh Printing, BPFE, Yogyakarta.

[10]. Munawir S., ( 2010 ) ,' Analysis of Financial Statements, Fourth Edition', Thirteenth Printing, Liberty, Yogyakarta.

[11]. As of OJK.05 / 2018 (2018),' concerning Financial Health for insurance companies'

[12]. Wild, Subramanyam, and Halsey. (2005).' Financial Statement Analysis' . Eighth edition. Translated by: Yanivi S. Bachtiar and S. Nurwahyu Harahap. Salemba Empat. Jakarta.

[13]. Irawati, S. (2005).' Financial Management' . Bandung: Library Publisher.

[14]. Cashmere. (2012),' Analysis of Financial Statements' . Jakarta: PT. Raja Grafindo Persada.

[15]. LM Samryn, ( 2011 ) ,' Introduction to Accounting, First Edition' , Publisher Raja Grafindo Persada, Jakarta.

[16]. S. Munawir, ( 2004)' Analysis of Financial Statements' , Liberty Publisher. Yogyakarta.

[17]. Irham Fahmi , (2012),' Analysis of Financial Statements', 2nd Printing, Bandung: Alfabeta

Cite this article as :

Sultan, Dr Teddy Oswari, "Influence of Activity Ratio to The Performance of Financial Statement of Badan BPJS Ketenagakerjaan Indonesia", International Journal of Scientific Research in Science and Technology (IJSRST), Online ISSN : 2395-602X, Print ISSN : 2395-6011, Volume 6 Issue 5, pp. 255-258, September-October 2019. Available at doi : https://doi.org/10.32628/IJSRST196474 Journal URL : http://ijsrst.com/IJSRST196474 